\title{
Gambaran Kasus Kejahatan Kekerasan Seksual di RS Bhayangkara Tingkat III Manado Periode Januari 2017-Desember 2019
}

\author{
Aditya P. Latjengke, ${ }^{1}$ Djemi Tomuka, ${ }^{2}$ Erwin G. Kristanto ${ }^{2}$
}

\author{
${ }^{1}$ Program Studi Pendidikan Dokter Fakultas Kedokteran Universitas Sam Ratulangi Manado \\ ${ }^{2}$ Bagian Ilmu Kedokteran Forensik Dan Medikolegal Fakultas Kedokteran Universitas Sam \\ Ratulangi Manado/RSUP Prof. Dr. R. D. Kandou \\ Email: adityapratamalatjengke06@gmail.com
}

\begin{abstract}
Rape or sexual violence is very prominent in this globalization era. This sudy was aimed to obtained the profile of sexual violence crimes in Forensic Department of RS Bhayangkara Tingkat III in the period of January 2017 to December 2019. This was a retrospective and descriptive study using visum et repertum. Data were presented in tables of frequency distribution. There were 305 cases of sexual violence crimes in this study; 152 cases were 12-16 years (teenagers). Most victims were females (304 cases); had occupation/education as students (184 cases); and lived in Manado (169 cases). Perpetrators of sexual violence crimes were friends of the victims (108 cases). In conclusion, the majority of sexual violence victims were 12-16 years old (teenagers), females, had occupation/education as students, and lived in Manado. Most perpetrators were friends of the victims.
\end{abstract}

Keywords: sexual violence crimes, victims, perpetrators

\begin{abstract}
Abstrak: Fenomena kejahatan pemerkosaan atau kekerasan seksual pada era globalisasi saat ini sangat menonjol. Penelitian ini bertujuan untuk mendapatkan gambaran kasus kejahatan kekerasan seksual di Bagian Forensik RS Bhayangkara Tingkat III Manado periode Januari 2017-Desember 2019. Jenis penelitian ialah deskriptif retrospektif dengan menggunakan hasil visum dan dilaporkan menurut distribusi frekuensi. Hasil penelitian mendapatkan 305 kasus kejahatan kekerasan seksual. Sebagian besar kasus kekerasan seksual berusia 12-16 tahun (masa remaja awal) yaitu 152 kasus. Jenis kelamin korban yang terbanyak ialah perempuan yaitu 304 kasus. Pekerjaan/pendidikan korban ialah pelajar sebanyak 184 kasus. Alamat korban terbanyak berada di Kota Manado yaitu 169 kasus. Pelaku kejahatan kekerasan seksual yang terbanyak ialah teman korban yaitu 108 kasus. Simpulan penelitian ini ialah mayoritas korban kasus kekerasan seksual di RS Bhayangkara Tingkat III Manado berusia 12-16 tahun, berjenis kelamin perempuan, pekerjaan/pendidikan sebagai pelajar dengan alamat di Kota Manado. Pelaku kekerasan seksual terbanyak ialah teman korban.

Kata kunci: kejahatan kekerasan seksual, korban, pelaku
\end{abstract}

\section{PENDAHULUAN}

Kekerasan terhadap perempuan sering kali terjadi di dalam lingkungan rumah tangga, baik dalam keluarga inti maupun keluarga yang diperluas. Korbannya dapat merupakan isteri, anak, atau asisten rumah tangga (ART). Jenis kekerasan pun bervariasi dari kekerasan fisik, kekerasan seksual, dan pencederaan psikologis. ${ }^{1}$

Perkosaan merupakan kejahatan yang serius dan bukti pelanggaran hak asasi manusia (HAM). Tindakan perkosaan menyebabkan trauma psikologis yang serius pada korban serta keluarga mengingat apa yang dilakukan pelaku telah mengakibatkan munculnya berbagai persoalan buruk yang dihadapi oleh korban dan juga ketakutan pada masyarakat (fear of society). Pasal 285 tentang pemerkosaan berbunyi: "Barang siapa dengan kekerasan atau dengan 
ancaman kekerasan memaksa orang perempuan diluar perkawinan bersetubuh dengan dia karena salahnya perkosaan, dihukum dengan hukuman penjara selamalamanya 12 tahun'. Jadi, dalam hal ini harus dibuktikan terlebih dahulu adanya suatu persetubuhan. ${ }^{1-3}$

Teknik ilmu kedokteran forensik biasa digunakan pada kejahatan yang serius seperti perkosaan dan pembunuhan. Perkembangan teknologi seperti pembuatan data base DNA dan sistem pencarian sidik jari secara otomatis memberikan perubahan yang sangat besar dalam bidang teknik forensik untuk membantu penyelidikan suatu kejahatan. Dewasa ini, perkembangan teknologi telah membawa perubahan secara keseluruhan dalam proses penyelidikan suatu kasus. ${ }^{2,3}$

Peran dan fungsi visum et repertum (VeR) sebagai salah satu alat bukti yang sah sebagaimana tertulis dalam pasal 184 KUHP. Visum et repertum turut berperan dalam proses pembuktian suatu perkara pidana terhadap kesehatan dan jiwa manusia serta menguraikan segala sesuatu tentang hasil pemeriksaan medis tersebut yang tertuang di dalam bagian simpulan. Dengan demikian VeR secara utuh telah menjembatani ilmu kedokteran dengan ilmu hukum sehingga dengan membaca VeR dapat diketahui dengan jelas apa yang telah terjadi pada seseorang, dan para praktisi hukum dapat menerapkan norma-norma hukum pada perkara pidana yang menyangkut tubuh dan jiwa manusia. ${ }^{4-6}$

Komisi Nasional Anti Kekerasan terhadap perempuan (Komnas perempuan) mencatat dalam kurun waktu 13 tahun (19982011) kasus kekerasan seksual berjumlah hampir seperempat dari seluruh total kasus kekerasan, atau 93.960 kasus dari seluruh kasus kekerasan terhadap perempuan yang dilaporkan (400.939). Hal ini berarti, setiap hari ada 20 perempuan yang menjadi korban kekerasan seksual. Data ini diperoleh dari dokumentasi catatan tahunan (CATAHU) Komnas perempuan bersama lembagalembaga layanan bagi perempuan korban, pemantauan Komnas perempuan tentang pengalaman kekerasan terhadap perempuan di dalam konteks Aceh, Poso, tragedi 1964, Ahmadiyah, Migrasi, Papua, Ruteng, pelaksanaan otonomi daerah, dan rujukan Komnas perempuan pada data dari tim gabungan pencari fakta (TGPF) peristiwa kerusuhan Mei 1998, serta komisi penerimaan, kebenaran dan rekonsiliasi Timor Leste (CAVR). ${ }^{7}$ KUHP pidana bab XIV mengatur tentang kejahatan terhadap kesusilaan yang di dalamnya tercakup kejahatan seksual. Dari 25 pasal, 15 pasal mengatur tentang keja hatan seksual dan jika dirinci lebih lanjut, maka bagian terbesar mengatur hubungan lelaki-perempuan yang dilarang. Homo seksualitas yang dilarang merupakan bagian kecil saja. ${ }^{3}$

Dengan mencermati tingginya kasus kekerasan seksual terhadap perempuan maka penulis tertarik untuk mengetahui gambaran kasus kejahatan kekerasan seksual di RS Bhayangkara Tingkat III Manado periode Januari 2017-Desember 2019

\section{METODE PENELITIAN}

Penelitian ini dilaksanakan pada bulan Februari-Juli 2020 di RS Bhayangkara Tingkat III Manado. Jenis penelitian ialah deskriptif retrospektif dengan menggunakan data sekunder dari hasil visum dan dilaporkan menurut distribusi frekuensi. Variabel penelitian ialah jumlah kasus kejahatan kekerasan seksual, usia korban, jenis kelamin korban, alamat korban, serta pekerjaan/pendidikan korban dan pelaku.

Penelitian ini telah mendapat persetujuan dari Komisi Etik Penelitian Kesehatan RSUP Prof. Dr. R. D. Kandou Manado, dengan nomor keterangan layak etik yaitu No. 056/EC/KEPK-KANDOU/VII/2020.

\section{HASIL PENELITIAN}

Gambar 1 memperlihatkan secara keseluruhan jumlah kasus kejahatan kekerasan seksual yang dilaporkan di RS Bhayangkara Tingkat III Manado selama 3 tahun yaitu 305 kasus. Kasus kejahatan kekerasan seksual yang terbanyak ialah pada tahun 2018 yaitu 154 kasus $(50,49 \%)$, diikuti oleh tahun 2019 sebanyak 76 (24,91\%) kasus, dan pada tahun 2017 sebanyak 75 kasus $(24,59 \%)$. 
Tabel 1 memperlihatkan jumlah korban kejadian kasus kejahatan kekerasan seksual terbanyak di tahun 2017 sampai 2019 yaitu pada usia masa remaja awal (12-16 tahun) sebanyak 152 kasus dan jumlah korban terendah sebanyak 1 kasus pada usia masa dewasa akhir 36-45 tahun. Tidak didapatkan kasus pada usia $\geq 56$ tahun.

Tabel 2 memperlihatkan bahwa kasus kejahatan kekerasan seksual menurut jenis kelamin perempuan berjumlah 304 orang, jauh lebih banyak dibandingkan dengan yang berjenis kelamin laki-laki berjumlah 1 orang.

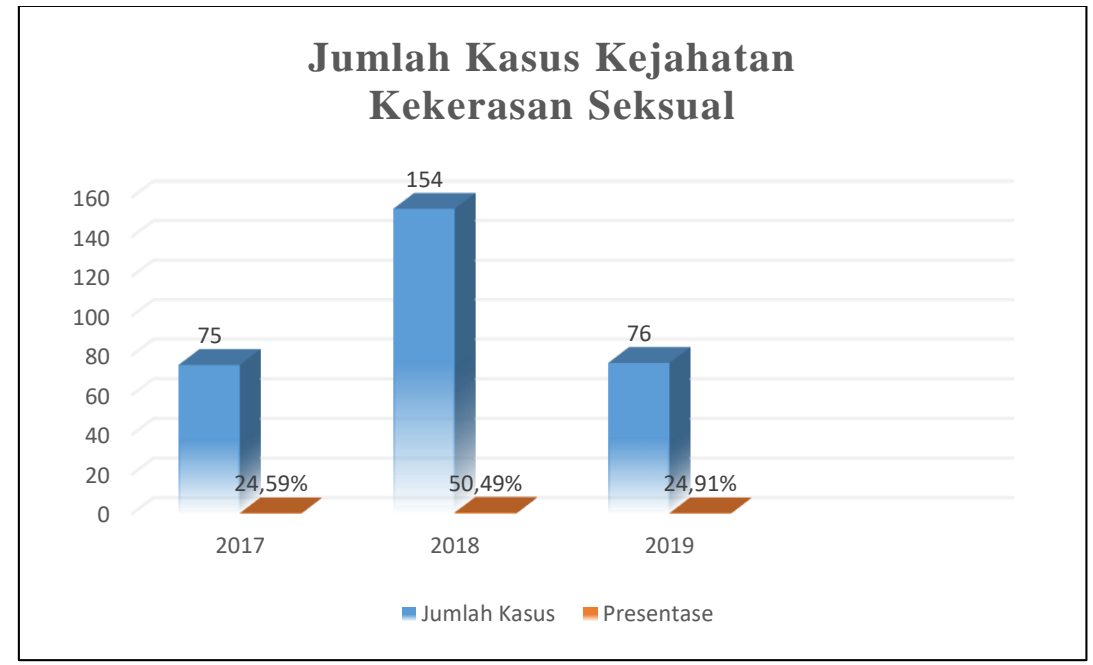

Gambar 1. Jumlah kasus kejahatan kekerasan seksual sesuai dengan data yang dilaporkan di RS Bhayangkara Tingkat III Manado

Tabel 1. Distribusi usia korban kasus kejahatan kekerasan seksual

\begin{tabular}{lcccc}
\hline \multicolumn{1}{c}{ Usia } & Tahun & Jumlah \\
& $\mathbf{2 0 1 7}$ & $\mathbf{2 0 1 8}$ & $\mathbf{2 0 1 9}$ & \\
\hline Masa balita 0-5 tahun & 3 & 13 & 2 & 18 \\
Masa kanak-kanak 5-11 tahun & 18 & 37 & 17 & 72 \\
Masa remaja awal 12-16 tahun & 40 & 73 & 39 & 152 \\
Masa remaja akhir 17-25 tahun & 12 & 24 & 16 & 52 \\
Masa dewasa awal 26-35 tahun & - & 4 & 1 & 5 \\
Masa dewasa akhir 36-45 tahun & - & 1 & - & 1 \\
Masa lansia awal 46-55 tahun & 2 & 2 & 1 & 5 \\
Masa lansia akhir 56-65 tahun & - & - & - & - \\
Masa manula >65 tahun & - & - & - & - \\
Total & 75 & 154 & 76 & 305 \\
\hline
\end{tabular}

Tabel 2. Jumlah kasus kejahatan kekerasan seksual berdasarkan jenis kelamin korban

\begin{tabular}{lcccc}
\hline Jenis Kelamin & \multicolumn{3}{c}{ Tahun } & Jumlah \\
& $\mathbf{2 0 1 7}$ & $\mathbf{2 0 1 8}$ & $\mathbf{2 0 1 9}$ & \\
\hline Perempuan & 75 & 153 & 76 & 304 \\
Laki-laki & - & 1 & - & 1 \\
Total & 75 & 154 & 76 & 305 \\
\hline
\end{tabular}


Tabel 3 memperlihatkan bahwa menurut pekerjaan/pendidikan pada tahun 2017 sampai 2019 didapatkan korban terbanyak yaitu pelajar dengan jumlah 184 kasus dan yang paling sedikit yaitu karyawan swasta dengan jumlah 8 kasus.

Tabel 4 memperlihatkan bahwa pada kasus kejahatan kekerasan seksual yang terjadi di tahun 2017, 2018 dan 2019 diperoleh data alamat korban yang terdiri dari 4 kota dan 8 kabupaten. Tiga lokasi yang menempati urutan tertinggi ialah Kota
Manado, disusul oleh Kabupaten Minahasa Utara, dan Kabupaten Minahasa.

Tabel 5 memperlihatkan bahwa yang paling banyak melakukan tindakan kekerasan seksual pada tahun 2017 sampai 2019 ialah teman korban dengan jumlah kasus sebanyak 108 kasus. Yang paling sedikit melakukan tindakan kekerasan seksual yaitu ART, supir taksi gelap, supir angkot, pemilik mobil rental, dan mantan pacar yang masing-masing berjumlah 1 kasus.

Tabel 3. Jumlah kasus kejahatan kekerasan seksual berdasarkan pekerjaan/ pendidikan korban

\begin{tabular}{lcccc}
\hline Pekerjaan/Pendidikan & & Tahun & & Jumlah \\
& $\mathbf{2 0 1 7}$ & $\mathbf{2 0 1 8}$ & $\mathbf{2 0 1 9}$ & \\
\hline Siswi TK & 2 & 13 & 2 & 17 \\
Siswi SD & 12 & 35 & 17 & 64 \\
Pelajar & 49 & 88 & 47 & 184 \\
Mahasiswa & 6 & 4 & 3 & 13 \\
IRT & 2 & 5 & 2 & 9 \\
Karyawan Swasta & 3 & 4 & 1 & 8 \\
Tidak ada & 1 & 5 & 4 & 10 \\
Total & 75 & 154 & 76 & 305 \\
\hline
\end{tabular}

Tabel 4. Jumlah kasus kejahatan kekerasan seksual berdasarkan alamat korban

\begin{tabular}{lcccc}
\hline \multicolumn{1}{c}{ Alamat } & Tahun & Tahis & 2019 & Jumlah \\
\hline Kota Manado & 42 & 91 & 36 & 169 \\
Kabupaten Minahasa & 4 & 13 & 11 & 28 \\
Kabupaten Minahasa Utara & 21 & 46 & 22 & 89 \\
Kabupaten Minahasa Selatan & 1 & 1 & 2 & 4 \\
Kabupaten Minahasa Tenggara & 1 & - & 1 & 2 \\
Kota Tomohon & - & - & 2 & 2 \\
Kabupaten Kepulauan Talaud & 1 & - & - & 1 \\
Kabupaten Kepulauan Sangihe & - & 1 & 1 & 2 \\
Kota Bitung & 2 & 1 & - & 3 \\
Kabupaten Bolmong & 2 & - & 1 & 3 \\
Kabupaten Bolmong Utara & - & 1 & - & 1 \\
Kota Kotamobagu & 1 & - & - & 1 \\
Total & 75 & 154 & 76 & 305 \\
\hline
\end{tabular}

Tabel 5. Jumlah kasus kejahatan kekerasan seksual berdasarkan pelaku

\begin{tabular}{lcccc}
\hline \multicolumn{1}{c}{ Pelaku } & \multicolumn{3}{c}{ Tahun } & Jumlah \\
& $\mathbf{2 0 1 7}$ & $\mathbf{2 0 1 8}$ & $\mathbf{2 0 1 9}$ & \\
\hline Keluarga & 5 & 2 & 5 & 12 \\
Ayah kandung & 5 & - & 7 & 12 \\
Ayah tiri & 1 & 1 & 1 & 3 \\
Saudara kandung & & & & \\
\hline
\end{tabular}




\begin{tabular}{lcccc}
\hline \multicolumn{1}{c}{ Saudara tiri } & - & 1 & - & 1 \\
$\quad$ Kakek kandung & - & 1 & - & 1 \\
$\quad$ Kakek tiri & - & - & 1 & 1 \\
$\quad$ Paman & 3 & 5 & 5 & 13 \\
$\quad$ Sepupu & 1 & 3 & - & 4 \\
Guru & - & 1 & 2 & 3 \\
Kerabat keluarga & 2 & 8 & 2 & 12 \\
ART & - & - & 1 & 1 \\
Kenalan & 1 & 9 & 6 & 16 \\
Orang tidak dikenal & 6 & 33 & 10 & 49 \\
Supir taksi gelap & - & 1 & - & 1 \\
Supir angkot & 2 & 1 & - & 3 \\
Pemilik mobil rental & 1 & - & - & 1 \\
Total & 75 & 154 & 76 & 305 \\
\hline
\end{tabular}

\section{BAHASAN}

Pada penelitian ini didapatkan 305 kasus kejahatan kekerasan seksual selama 3 tahun berturut-turut yaitu tahun 2017, 2018, dan 2019. Jumlah kasus tertinggi didapatkan pada tahun 2018 yaitu 154 kasus $(50,49 \%)$, diikuti oleh kasus pada tahun 2019 sebanyak $76(24,91 \%)$ kasus, dan pada pada tahun 2017 sebanyak 75 kasus $(24,59 \%)$.

Hasil penelitian mendapatkan bahwa korban kejadian kasus kejahatan kekerasan seksual di tahun 2017 sampai 2019 terbanyak pada usia masa remaja awal (12-16 tahun) dan yang terendah pada usia masa dewasa akhir 36-45 tahun. Hal ini agak berbeda dengan data kasus kekerasaan seksual di RS Bhayangkara Kota Dumai Provinsi Riau (2009-2013) yang mendapatkan 119 korban, yaitu terbanyak berada pada usia 0-18 tahun dan terendah berada pada usia $>45$ tahun sebanyak 0 korban. ${ }^{6}$ Data mengenai karakteristik korban di ranah privat dan komunitas menurut Komnas perempuan melalui data dan layanan CATAHU memperlihatkan bahwa usia korban paling tinggi berada pada kisaran usia 25-40 tahun, yaitu pada usia produktif. Namun yang perlu menjadi perhatian ialah data korban cukup tinggi ialah pada usia anak (dibawah 18 tahun). ${ }^{7}$ Hal ini dapat disebabkan karena kurangnya pengawasan dari orang tua.

Pada penelitian ini didapatkan bahwa jumlah kasus kejahatan kekerasan seksual di RS Bhayangkara Tingkat III Manado dengan korban terbanyak ialah perempuan. Hal ini sejalan dengan Laporan Kinerja Instansi Pemerintah (LKIP) Dinas Pemberdayaan Perempuan dan Perlindungan Anak di Kota Makassar tahun 2018 yang melaporkan kekerasaan seksual terhadap perempuan dan anak, yaitu dari 30 kasus kekerasan seksual, 25 kasus korbannya ialah perempuan dan 5 kasus ialah anak laki-laki. ${ }^{8}$ Data dari WHO menjelaskan 1 dari 5 perempuan dan 1 dari 13 laki-laki melaporkan pernah mengalami kekerasan seksual saat usia anak/remaja. ${ }^{9}$

Pada penelitian ini didapatkan bahwa menurut pekerjaan/pendidikan korban yang terbanyak yaitu pelajar (184 kasus) dan yang paling sedikit yaitu karyawan swasta (8 kasus). Data kasus kekerasaan seksual di RS Bhayangkara Kota Dumai Provinsi Riau juga mendapatkan gambaran pekerjaan korban hidup kasus kekerasan seksual yang tertinggi ialah pelajar sebanyak 71 korban, sedangkan yang terendah ialah wiraswasta sebanyak 5 korban. ${ }^{6}$ Data profesi CATAHU menunjukkan bahwa kekerasan seksual terhadap perempuan korban paling banyak sebagai pelajar. Hampir semua data tersebut melaporkan bahwa yang tertinggi ialah tidak terdentifikasi yang dapat disebabkan oleh masalah pendokumentasian atas faktor tersebut atau masalah administrasi kependu- 
dukan yang belum sinkron dengan pendokumentasian pengaduan kasus. ${ }^{7}$

Pada penelitian ini didapatkan data alamat kasus kejahatan kekerasan seksual yang terjadi pada tahun 2017, 2018 dan 2019 di 4 kota dan 8 kabupaten. Tiga lokasi yang menempati urutan tertinggi ialah Kota Manado, disusul oleh Kabupaten Minahasa Utara, dan Kabupaten Minahasa. Data Pusat Pelayanan Terpadu Pemberdayaan Perempuan dan Anak (P2TP2A) dari Dinas Pemberdayaan, Perlindungan Anak dan Pengendalian Penduduk (DPPAPP) menyatakan jumlah korban kekerasaan seksual di DKI Jakarta tahun 2018 sebanyak 761 kasus. ${ }^{10}$ Kekerasan seksual terhadap perempuan berdasarkan provinsi pada data CATAHU tahun 2018 menyatakan bahwa yang tertinggi di Jawa Barat sebanyak (2.738), lalu Jawa Tengah (2.525) dan DKI Jakarta (2.222) sedangkan tahun sebelumnya dilaporkan angka kekerasan seksual tertinggi ialah Jawa Tengah (2.913), DKI Jakarta (2.318) dan Jawa Timur (1.944). Komnas Perempuan melihat tingginya angka berkaitan dengan jumlah tersedianya lembaga pengada layanan di provinsi tersebut serta kualitas dan kapasitas pendokumentasian lembaga. ${ }^{7}$

Hasil penelitian ini mendapatkan bahwa pelaku kekerasan seksual pada tahun 2017 sampai 2019 yang terbanyak ialah teman korban (108 kasus) dan yang paling sedikit ialah ART, supir taksi gelap, supir angkot, pemilik mobil rental, dan mantan pacar (masing-masing berjumlah 1 kasus). Data yang didaptkan di Pusat Pelayanan Terpadu Pemberdayaan Perempuan dan Anak (P2TP2A) provinsi Riau mencatat pelaku kejahatan seksual lebih banyak ialah orang terdekat korban. ${ }^{11}$ Melihat tingginya angka kekerasan seksual Komnas perempuan melalui data dan layanan CATAHU mendapatkan hal yang berbeda pada tahun 2017 dimana pelaku kekerasan seksual tertinggi ialah teman, sedangkan tahun 2018 pelaku tertinggi ialah orang tidak dikenal. Data CATAHU selama 3 tahun terakhir mendapatkan bahwa anak berusia kurang dari 18 tahun berpotensi menjadi pelaku pertahun, dengan kata lain setiap hari ada anak menjadi pelaku kekerasan. ${ }^{7}$

Remaja merupakan kelompok atau golongan yang mudah dipengaruhi karena remaja sedang mencari identitas diri sehingga mereka dengan mudah untuk meniru atau mencontoh apa yang dilihat, seperti pada film pornografi atau berita yang sifatnya kekerasan, dan sebagainya. Perkembangan tenknologi modern saat ini seperti mengakses informasi dengan cepat, mudah dan tanpa batas juga memudahkan remaja untuk mendapatkan hiburan yang tidak sesuai dengan mereka. Selain itu remaja melakukan perkosaan karena dipengaruhi oleh minuman keras. ${ }^{12}$

\section{SIMPULAN}

Mayoritas korban kekerasan seksual di RS Bhayangkara Tingkat III Manado berusia 12-16 tahun, berjenis kelamin perempuan, pekerjaan/pendidikan sebagai pelajar dengan alamat di Kota Manado. Pelaku kekerasan seksual terbanyak ialah teman korban.

Bagi peneliti lanjut disarankan agar memperdalam mengenai kasus kejahatan kekerasan seksual dengan cara berkomunikasi bukan hanya dari sudut pandang pendamping, namun juga dari sudut pandang korban yang berpengaruh terhadap kesembuhan pasien, Orang tua sebaiknya memberikan edukasi seksual sejak dini, menjalin komunikasi yang baik dengan anak, dan menjaga anak-anaknya dari ancaman pelaku perkosaan yang saat ini marak terjadi di Indonesia, Pemerintah sebaiknya segera mengambil langkah nyata untuk memberikan efek jera kepada pelaku pemerkosaan dan bekerjasama dengan Komnas Perempuan untuk peningkatan kualitas pelayanan di bidang kelengkapan sarana dan prasarana. Selain itu perlu dikembangkan program-program pemberdayaan perempuan yang lebih luas lagi, tidak hanya sebatas pemberdayaan psikologis dan pemberdayaan hukum saja.

\section{Konflik Kepentingan}

Penulis menyatakan tidak terdapat konflik kepentingan dalam studi ini. 


\section{DAFTAR PUSTAKA}

1. Sampurna B, Samsu Z, Siswaja TD. Peranan Ilmu Forensik dalam Penegakan Hukum (1st ed) Jakarta: FKUI, 2008.

2. Bradbury SA, Feist A. The use of forensic science in volume crime investigations: a review of the research literature. Home office online report 43/05. Crime Reduction and Community Safety Group, 2005. Available from: http: //library.college.police.uk/docs/hords olr/rdsolr4305.pdf

3. Murtika IK, Prakoso D. Dasar-dasar Ilmu Kedokteran Kehakiman (Cetakan ke-2). Jakarta: Rineka Cipta, 1992; p. 110-2.

4. Suryanti, Pujihastuti A. Tinjauan alur prosedur pembuatan visum et repertum di Rumah Sakit Panti Waluyo Surakarta tahun 2010. Jurnal Kesehatan. 2010;IV(I):3542.

5. Wahid A. Perlindungan terhadap Korban Kekerasan Seksual Advokasi atas Hak Asasi Perempuan, Bandung: Reflika Aditama, 2001; p. 27-32.

6. Indrayana MT. Profil kasus kekerasan seksual terhadap perempuan dan anak yang diperiksa di RS Bhayangkara Dumai (2009-2013). Jurnal Kesehatan Melayu. 2017;1(1):9.

DOI: $10.26891 / \mathrm{jkm} . v 1 \mathrm{i} 1.19$

7. Aryani AV, Mustafainah A, Khusnaeny A, Purba C, Purbawati CY, Madani D, et al. Korban bersuara data bicara sahkan UU penghapusan kekerasan seksual sebagai wujud komitmen negara. Catat-an terhadap Perempuan Tahun 2018. Komnas Perempuan: Jakarta 6 Maret 2019. [cited 2020 July 28]. Available from: https://www.komnasperempuan. go.id

8. Palallo TA. Kinerja Instansi Pemerintah (LKIP) Dinas Pemberdayaan Perempuan dan Perlindungan Anak Kota Makassar, 2018. [cited 2020 Aug 13]. Available from: http://dp3a.makassar.go.id/wpcontent/uploads/2018/08/LKIPDPPPA-2018.

9. Mardina R. Kekerasan terhadap anak dan Remaja. Pusat Data dan Informasi Kementrian Kesehatan RI. Available from: http://www.kemkes.go.id.

10. Nisa K. Meningkatnya jumlah korban kekerasan perempuan dan anak yang melapor ke lembaga pelayanan. Pusat Pelayanan Terpadu Pemberdayaan Perempuan dan Anak (P2TP2A). Published, April 18, 2019. [cited 2020 Aug 13]. Available from: http://statistik.jakarta.go.id/meningkatnya-jumlah-korbankekerasan-perempuan-dan-anak-yangmelapor-ke-lembaga-pelayanan/

11. Arief Y. Studi kasus gambaran kepribadian pelaku sodomi. Jurnal Universitas Islam Riau. 2016;7(1):59-64. DOI: https:// doi.org/10.15548/alqalb.v7i1.838

12. Sarlita BP. Perilaku perkosaan pada remaja [Skripsi]. Surakarta: Universitas Muhammadiyah Surakarta; 2018. 